\title{
The Plight of the Whales
}

$$
\text { By J.A. Gulland }
$$

Even at the time that Herman Melville wrote Moby Dick whalers were alarmed at the decline in whale stocks. To-day the situation is so serious as a result of overhunting that the whaling industry, which could produce more than half a million tons of meat and edible oils a year, is destroying itself. John Gulland, of the Fisheries Research Laboratory at Lowestoft, was one of the Committee of four scientists appointed by the Whaling Commission to investigate the whale stocks. Their report last summer showed how serious the depletion had been. Nevertheless, the recommendations for cuts in the whale quotas were rejected by the four whaling countries. In this article, originally broadcast by the B.B.C., Mr Gulland suggests an ingenious solution which he regards as the only hope for saving both whales and whaling.

THIRTY years ago nearly 30,000 blue whales were caught in a

single season: last year the number was barely a hundred. This dramatic and catastrophic decline is typical of the collapse of other whale fisheries during the course of history. For example, a thousand years ago the Basques hunted whales in the Bay of Biscay; there is a whale and a whaling boat on the crest of the town of Biarritz. But by the fifteenth century the whales they hunted had virtually disappeared and whaling had ceased. Then again, around the seventeenth century the English and Dutch whalers-and some others-developed the Arctic whaling grounds. It was at this time that the prosperity of Dundee and other ports was founded. Year by year they had to move further north up the coasts of Greenland and Spitsbergen, as far as the ice allowed them, but Arctic whaling remained profitable for a hundred years or more. Then by the middle of the last century the number of the Arctic right whales was clearly declining-the last whaler to sail from Dundee to the Arctic returned home fifty years ago-without a whale.

I can repeat this dismal story for other oceans, but the latest version began with the development of the floating factory ship after the first world war. Then whalers, especially the Norwegians, started to hunt the great stocks of whales in the vast Antarctic ocean. Within twenty years it was clear that the numbers of the blue whale were declining. Even before the last war, to maintain their catches the whalers were turning more and more to the fin whale - the blue whale's slightly smaller relative. Now the blue whales are so scarce that they are possibly close to extinction, and even the number of the fin whale is falling rapidly towards the point where Antarctic whaling is no longer going to be economically possible. An industry will have disappeared that annually produced for a hungry world a quarter of a million tons of valuable edible oils, and another quarter of a million tons of by-products such as frozen meat. 
The simple reason for the decline in whale stocks is perfectly obvious - too many whales are being caught, and too few are being left in the sea to breed and produce next year's crop. Recently whaling scientists from all countries, and in particular a group of four from uncommitted countries-New Zealand, United States, myself from England, and one from the Food and Agriculture Organisation of the United Nations, have made a detailed study of the state of the Antarctic whale stocks. We have been able to calculate the numbers of whales in the Antarctic, and explain numerically what has been happening to them. We found that around one-third of the whales present at the beginning of a whaling season will be caught during that season. Adding all the species together, the annual take of whales from the Antarctic which could be taken year after year from stocks at the ideal level is some tens of thousands. This represents well over half a million tons of edible oils and meat, and it is an appreciable contribution to the world's food supply. Unfortunately, the stocks are now reduced far below the levels that can give the maximum sustainable yields, and because of the low birth rate, the stocks can only build up slowly. The blue whales are so few that it would take fifty years of complete protection for them to reach sufficient numbers to give an appreciable yield; the real question is whether they have already been reduced so far that they are in grave danger of complete extermination. The fin whales are not in so bad a state, but with the present intensive catching within a few years they too will be so reduced that they will be unable to recover to a useful level within any reasonable time.

\section{"So Remorseless a Havoc"}

This is not a new question: Herman Melville asked it in Moby Dick :

"But still another inquiry remains; one often agitated by the more recondite Nantucketers. Whether owing to the almost omniscient look-outs at the mast-heads of the whale-ships, now penetrating even through Behring's straits, and into the remotest secret drawers and lockers of the world; and the thousand harpoons and lances darted along all continental coasts; the moot point is, whether Leviathan can long endure so wide a chase, and so remorseless a havoc; whether he must not at last be exterminated from the waters, and the last whale, like the last man, smoke his last pipe, and then himself evaporate in the final puff."

Melville's question is not now an interesting problem to be discussed in the foc'sle of a whaler, but a matter of definite choice-are we prepared to risk the extinction of the world's largest animal, and the end of an industry capable of producing great quantities of food for a hungry world? This is perhaps unfair to whalers, and the whaling industry. As Melville shows, they have been worried for some time about the whale stocks and how long they could stand intensive hunting.

After some preliminary discussions before the war, the first positive 
step in conservation was taken in December 1946, when the International Whaling Convention was signed. This Convention was set up by the International Whaling Commission, to ensure complete protection of some of the smaller stocks of whales-such as right whales everywhere, and humpbacks and other whales in the North Atlanticmost of which have anyway been so depleted by too heavy exploitation that they cannot now provide worthwhile catches even if catching were allowed. More important, the Commission sets a quota for the total catch of whales that may be taken from the Antarctic. Potentially, this gives us a very good method of managing the stocks; a quota set at the sustainable yield of the present stock means that the stock will stay at its present level. If we want the stock to increase towards the level giving the maximum sustainable yield, then the quota can be set a little below the sustainable yield, and so the stock builds up.

Sadly this did not work out quite so well in practice. The first trouble was that the quota did not distinguish between the different species of whales. When they can choose, the whalers prefer to catch a blue whale, which may weigh as much as a hundred tons, rather than a smaller fin whale. At first all the attention was concentrated on blue whales, and little on fin whales, and for some years far too many blue whales were caught-and possibly not enough fin whales. Very quickly the blue whales were reduced to a level where they only made up a small fraction of the catch, and even then these small catches were more than the stock could stand, so that they were reduced to the present near extinction level. Most of the catches since 1950 have been fin whales, and the quota set was quite close to the maximum sustainable yield of this species. Unfortunately, it was set just too high-perhaps no more than ten per cent too high, but high enough to reduce the stocks even though at first they fell only slowly.

\section{Short-Term Interests Prevailed}

As the stocks decreased, so the sustainable yield decreased. The gap between the quota and the sustainable yield widened, and so the rate of decline accelerated. The decline in the fin whale stocks soon became apparent, and the Whaling Commission was urged to reduce the quota. But, as a three-quarters majority was needed, the short term interests of the whaling companies, who are very strongly represented on the Commission, were enough to prevent any action being taken. This was done on the grounds that at that time there was insufficient scientific evidence to measure the decrease in the stocks. Even though the quotas were not reduced a positive step was taken in setting up a special committee of three (later four) scientists to investigate the state of the Antarctic stocks and the need for conservation measuresthis was where I came into it.

The critical meeting of the International Whaling Commission was held last summer in the home of modern whaling, at Sandefjord in Norway. At this meeting the special committee presented its report. We made it clear, beyond all reasonable doubt, that the stocks of whales had already been greatly reduced, and that sustainable catches 
of a reasonable size could only be taken again if the present catches were greatly reduced to allow the stocks to build up again. Our conclusions were confirmed by the collapse of the fin-whale catches last year. In each season up to 1962 , they had been around 25,000 , which was the level of the quota, but then fell to only 13,853 last season. Though far below the quota level, this figure was only 150 different from the catches that the four of us had predicted. There was little or no argument with the scientific findings, but, despite this, the four countries actively engaged in Antarctic whaling-Japan, the Netherlands, Norway and Russia-would not agree to any significant reduction of the quota, because, they said, their industries were in such a poor condition that they could not afford a greater degree of interference with their activities. So, even though all the other member countries voted in favour of a drastic reduction, the necessary threequarters majority was not reached and no cut was made.

The reason for this failure lies in the balance sheets of the whaling companies (or their equivalent in Russia), and in the fact that in these balance sheets there is no entry corresponding to the capital value of the whales in the sea. That is, whales belong to no one until they are caught, and so it is in no one's direct interest to maintain the stocks.

\section{Who Should Own the Whales?}

To me the only solution seems to be that whales must belong to someone. The most appropriate body is clearly the United Nationsor one of its specialised agencies. This is an optimistic idea-but it is by no means fanciful. Clearly the present whaling countries are only likely to agree to stop whaling, and turn their interests over to the United Nations, if they are paid compensation. Two facts make this a practicable possibility: firstly, when the stocks have built up, the value of the sustainable catch will be very much more than the cost of catching it, probably around $\mathfrak{f 5 0}$ million per year income-with less that $£ 30$ million costs; a surplus of $£ 20$ million would be a considerable annual contribution to the United Nations' finances. Secondly, whatever the golden prospects under single ownership, with conservation failing, the present prospect is that whaling cannot continue to be profitable for more than a very few years. This the whaling companies realise, and so their compensation for withdrawing from whaling would be for only a few years' potential profits, and would be relatively small, probably less than the profits from one or two years' operations at a high level of stocks.

Thus, if the money for compensation were provided as a loan to what might be called the United Nations Whaling Agency, once the stocks had been built up, the loan could be quickly repaid. Until then, some small scale whaling could provide enough to pay off the interest on the loan. This may seem too idealistic ever to occur; it depends not only on the loan for compensation being provided, but also on the agreement of all the countries concerned, not only those at present whaling in the Antarctic, but also any others that might be tempted 
to go whaling when the stocks increase. But if this is a dream, then the alternative, the present lack of any effective conservation, is a nightmare. We are running rapidly towards the possible extinction of the whale, and to the certain extinction of the whaling industry, and the food it supplies to the world.

\section{THE NEW WHALING AGREEMENTS}

$\mathbf{M}^{\mathrm{o}}$ ORE jam for the whalers this year, and a promise to be less greedy next year and the year after, are the main results of the two meetings of the International Whaling Commission in London this year. The outcome for the whales cannot be said to be hopeful, at any rate for those who take a realistic view of international promises to do better in future. Last season the catches were more than twice the amount the stocks could stand - though they were less than the whaling countries expected to get-and were only maintained by the whalers concentrating on the sei whale (a smaller relative of the blue and fin whales). Before 1963 sei whales were not of much interest to the whalers, but in the $1964 / 5$ season some 20,000 were killed-about one-third of the total Antarctic stock.

Faced with a recommendation from their scientific advisers that, in order to prevent the further depletion of stocks, not more than 2,500 blue whale units should be taken in 1965/66 (one b.w.u. equals two fin whales or six sei whales), the IWC at its May meeting could do no better than agree on a compromise proposal of nearly double this figure, 4,500 , with a promise to accept realistic quotas in $1966 / 67$ and $1967 / 68$ that would ensure the rebuilding of world stocks. As has happened before, most countries agreed to an unrealistic figure in order to preserve the pretence of adherence to an international agreement. This decision was confirmed at the second London meeting in June, which also decided to look into the questions of incorporating the catches of the land stations into the quota system, and the conservation of whale stocks in the North Pacific.

The FPS was represented by observers at both meetings of the IWC, and had urged the adoption of three measures: the adoption of realistic quotas to allow the vastly depleted stocks to build up again; the incorporation of the land stations' catches in the quota system; and separate quotas for individual whale species instead of the overall blue whale unit. The first two of these may or may not be achieved next year.

On the credit side can be placed the agreement to prohibit the taking of blue and humpback whales in the North Pacific, though against this it has to be remembered that any country may object to these proposals within 90 days of the meeting. This is what happened over the total protection of the blue whale in the Antarctic proposed at the last meeting: all the pelagic whaling countries objected. The result is that blue whales are still not protected in Antaretic waters north of $55^{\circ}$ between $0^{\circ}$ and $80^{\circ}$ East. Informed world opinion will condemn Norway, Japan and Russia for this extraordinary piece of short-sightedness.

One reason for the Japanese insistence on an unrealistically large quota in $1965 / 66$ is the failure of the Russians to agree on the international observer scheme, designed to check that all whaling ships observe the quotas. The reason for the Russian attitude is probably to be found in the doubts about the reliability of many of the whale statistics, the majority of which, as the "New Scientist" has pointed out, appear to be doctored in one way or another. The other main Japanese motive is the need to recoup on the large capital expenditure on their whaling fleet. Once more short term considerations of finance have been allowed to risk the long-term destruction of a natural resource. 